\title{
Article
}

\section{Vegetation in Bangalore's Slums: Boosting Livelihoods, Well-Being and Social Capital}

\section{Divya Gopal ${ }^{1,2, \dagger, *}$ and Harini Nagendra ${ }^{3,4, \dagger}$}

1 Department of Ecology, Ecosystem Science/Plant Ecology, Technische Universität Berlin, Rothenburgstr. 12, 12165 Berlin, Germany

2 Institute of Botany and Landscape Ecology, University of Greifswald, Soldmannstr. 15, D-17487 Greifswald, Germany

3 School of Development, Azim Premji University, PES Institute of Technology Campus, Pixel Park, B Block, Electronics City, Hosur Road, Bangalore 560100, India; E-Mail: harini.nagendra@apu.edu.in

4 Ashoka Trust for Research in Ecology and the Environment (ATREE), Royal Enclave, Srirampura, Bangalore 560064, India

$\dagger$ These authors contributed equally to this work.

* Author to whom correspondence should be addressed; E-Mail: div.gopal@gmail.com; Tel.: +49-30-3147-1282.

Received: 24 January 2014; in revised form: 21 April 2014 / Accepted: 22 April 2014 / Published: 28 April 2014

Abstract: Urban greenery provides ecosystem services that play an important role in the challenging context of urban deprivation and poverty. This study assesses the social importance of vegetation through empirical assessment of 44 urban slums in the rapidly developing southern city of Bangalore, India. Vegetation played a major role in supporting nutrition by its role in food consumption, and in promoting health through the planting of species with medicinal use. Trees in slums also formed nodes for social activities including conversing and playing, domestic activities such as cooking and washing dishes, and livelihood activities such as the manufacture of broomsticks and tyre repair. Innovative methods of gardening were widely adopted, with kitchen gardens found planted in plastic bags, paint cans, old kitchen utensils and buckets, indicating the importance given to planting in environments with limited finances. Short and narrow trunked trees with medium-sized canopies and high economic value, such as Pongamia, were preferred. A greater focus on greening in slums is needed, and can provide an invaluable, inexpensive and sustainable approach to improve lives in these congested, deprived environments. 
Keywords: India; livelihood; slum dwellers; urban poverty; social ecological systems; urban ecology; urban vegetation

\section{Introduction}

Green spaces occupy an important function in the urban context and provide critical ecosystem services in congested urban environments, where more than half of the world's population is located [1]. Sustainable cities depend on a healthy ecosystem that influences both human well-being and numerous economic activities [2]. Trees in cities absorb vehicular air pollutants, buffer noise, regulate temperature and provide much-needed shade from the sun in tropical and sub-tropical belts [3-5]. Greenery near residential areas promotes walking, thereby improving people's cardiovascular systems and reducing obesity [6]. Green surroundings and home gardens reduce morbidity, increasing mental peace [7]. In countries like India and South Africa, green spaces, including home gardens, are often composed of socio-culturally important medicinal, sacred and culinary plants [8,9].

However, the benefits provided by trees and shrubs are not spatially homogeneous in cities. In particular, the availability of green spaces is limited in pockets of urban poverty, where access to private green spaces is often non-existent. Under such conditions, what is the role played by green spaces in the challenging context of urban deprivation and poverty?

While some studies have assessed the impact of greenery on poverty employing a psychological approach, others have enumerated its role in terms of food security. Kuo [10] suggests that neighbourhood greenery reduces mental fatigue, and provides greater psychological resources that can equip residents in low income districts to cope with poverty in the United States of America. Van den Berg et al. [11] in a study in the Netherlands, add that access to green space can help residents cope better with stressful life events, especially those related to poverty. With regard to food security, studies have shown that home gardens and community gardens in low income areas are the most economic and readily available sources of nutrition [12-14]. Thus, it seems possible that greenery within neighbourhoods is of great importance in the context of urban poverty.

Furthermore, Gallaher et al. [13] suggest that community gardening in and around residential areas increases social capital. This form of capital refers to the social relationships such as networks, norms and social trust within communities that promote cooperation for mutual benefit [15]. Moreover, it is the social resource upon which people depend while pursuing their livelihoods [16]. Social capital contributes to resilience by strengthening friendship and cooperation with neighbours and promoting household safety and survival $[15,17]$.

We seek to explore the socio-cultural importance of urban greenery in the context of poverty. This aspect of urban greenery has largely been overlooked in research, yet it is especially important in rapidly developing countries like India, where challenges of urban inequality are severe and accelerating. Indian slums are very densely populated, containing at least as many as 40 million inhabitants [18]. Squatter settlements in Indian cities are often small and interspersed among other wealthier neighbourhoods, to which they provide important services, including labour. 
Based on empirical assessments of 44 slums in Bangalore, India, we seek to understand the socio-cultural ecosystem services provided by vegetation in the context of urban poverty. Our first objective is to assess the species-specific characteristics (medicinal, culinary, ornamental, shade-giving etc.) of the vegetation encountered in slums, relating this to their contribution towards health and well-being. Second, we evaluate the contribution of trees towards social capital, by recording the occupations and activities carried out under their canopy, as well as the role played by trees beyond their inherent characteristics, in providing facilities such as physical support. Third, we assess the cultural services provided by trees in slums that strengthen social capital, by focusing on the sacred species found in slums. Fourth, through interviews with slum residents, we identify their requirements of urban greenery, using these to propose strategies for the improvement of the livelihoods of slum dwellers. Our findings enable us to add to our understanding of the socio-cultural importance of vegetation in the context of urban poverty, an aspect that has been insufficiently characterized thus far.

\section{Study Area and Methods}

A small village in the 12th century, Bangalore has grown both horizontally and vertically ever since, with a population that has recently surpassed 10 million. The city is dealing with the challenges of rapid and unplanned urbanization, including high traffic density, immense pressure on land, and an increasing number of slums [19]. Although there are more than half a million people living in the slums of Bangalore [20], government datasets lack an updated and complete slum profile. The composition and structure of urban greenery in parks, avenues, residential areas and other institutions in Bangalore have been well described [8,21-23], but there has been little research on the role played by green spaces in poor areas, especially slum settlements.

Surveys were conducted using the administrative boundary of greater Bangalore or the Bruhat Bengaluru Mahanagara Palike. Procuring reliable data on the number of slums in Bangalore and the profile of each slum was challenging, as various assessments have been carried out by a variety of government agencies and NGOs that do not concur with each other. One of the most recent and detailed reports is that published by the National Institute of Urban Affairs [24], with a non-exhaustive but detailed assessment of 114 slums within the city. Using this information, all slums mentioned in the report were visited. Given the extremely dynamic nature of urban growth in Bangalore [19,25], we found some slums to have been legalized and converted to residential areas, and others to have been razed. Furthermore, we found a number of areas that were identified as slums, but were in reality village settlements that had been engulfed by the rapid growth of the city. These locations were excluded from the study. In total, we surveyed a set of 44 slums identified in the report, covering a total area of 51.63 hectares (Figure 1). Field studies were carried out in May and June, 2011.

Typically, the slums in this study had densely packed housing units including shacks, huts, tents, pukka (made of durable materials such as concrete and brick) houses and kacha (made of natural materials such as mud and thatch) houses with narrow lanes, irregularly interspersed with trees, and with potted plants placed in and around the restricted space associated with most households. A complete census of the vegetation (both trees and plants) within the core structure of the slum as well as that around the slum periphery was carried out, with all trees and plants were identified to the species level. 
Figure 1. Location of surveyed slums in Bangalore with reference to the administrative boundary.

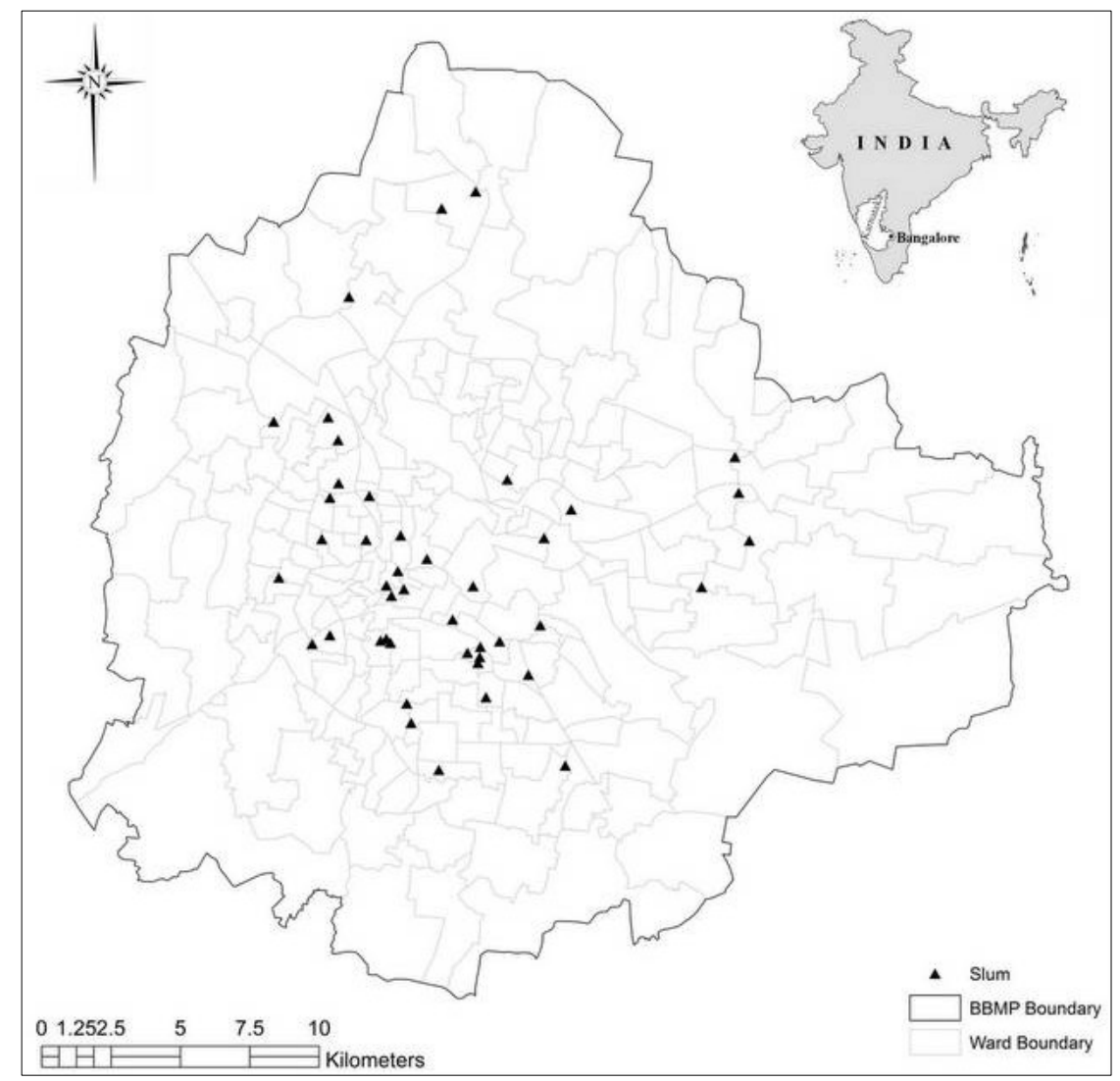

Visual observations of the utility of trees by slum dwellers were documented. Utility refers to the usage of trees as objects that can act as storage space, support, etc. as well as a platform for performing various day-to-day activities. These were documented based on our visual observations as well as those mentioned by the slum dwellers. However, the occupations and activities observed were limited to those carried out in the dry summer season. Bangalore receives copious sunshine throughout the year, with about 60 rainy days per annum [19]. Except for the short monsoon period, it is possible that most of the outdoor occupations are carried out throughout the year. Despite this, we acknowledge the fact that certain activities may vary over time and, therefore, limit our claims to the summer months, when the solar radiations are severe and the dependence on tree shade is at a maximum.

A study of the socio-cultural component would be incomplete without including the sacredness of nature in the Indian context. Therefore, sacred trees in slums - those described in sacred texts as well as those with holy symbols (dots of kumkum or the holy red powder and turmeric powder) and garlands - were recorded separately, and identified to the species level. Attributes of tree species such as origin and uses were assessed with reference to Neginhal [26] and Krishen [27]. Relative abundance was calculated for the tree species, giving an insight into the overall sum of abundance across the 44 slums.

Shrubs, herbs and creepers (referred to as plants hereafter) were also identified to the species level in each slum - except for nine genera of highly hybridized ornamental plants. The presence of plant species were documented instead of abundance. The species richness, i.e. the number of species per study site, was recorded for each slum. Attributes of plants were identified with reference to Kehimkar [28] and Kurian [29]. We also documented the types of pots used to grow these species. 
Additionally, we carried out open-ended group interviews in all slums, in order to understand the preferences of slum inhabitants for vegetation in their neighbourhood (i.e., if they want more greenery and the reason for their choice), and preferences for specific species, if any. The respondents were mainly women (primarily homemakers), with a group size of 5-8 individuals per slum.

\section{Results}

\subsection{Species Attributes}

A total of 553 trees belonging to 46 species (Table S1) were encountered in the 44 slums that we surveyed. In addition, we recorded 95 species of shrubs, herbs and creepers (Table S2). The most dominant tree encountered was Moringa oleifera (drumstick tree), widely consumed as a vegetable (Table 1). It is native to Bangalore and highly valued in southern India. Nearly half the tree population in slums had medicinal properties, while one-third were grown for their fruits. Muntingia calabura (Singapore cherry tree) and Mangifera indica (Indian mango tree) were the most popular fruiting trees. Albizia saman (rain tree) was the most dominant ornamental tree found, while Pongamia pinnata (pongam tree) was the tree largely grown for shade. The categories based on attributes, however, were not mutually exclusive, with some species having more than one use (Table 1).

Table 1. Overview of the ten most dominant tree species in the slums of Bangalore - abundance, attributes and activities (non-exhaustive) observed under the canopy.

\begin{tabular}{|c|c|c|c|c|}
\hline Scientific Name & Common Name & $\begin{array}{c}\text { Relative } \\
\text { Abundance } \\
\end{array}$ & Uses & $\begin{array}{l}\text { Activities Observed } \\
\text { (Non-Exhaustive) }\end{array}$ \\
\hline Moringa oleifera & Drumstick tree & 16.0 & $\begin{array}{c}\text { Fruits } \\
\text { Medicinal }\end{array}$ & $\begin{array}{l}\text { Adults playing } \\
\text { Children playing } \\
\text { Food source } \\
\text { Grooming } \\
\text { Socializing } \\
\end{array}$ \\
\hline Cocos nucifera & Coconut tree & 12.9 & $\begin{array}{c}\text { Fruits } \\
\text { Coir } \\
\text { Oil, etc. }\end{array}$ & $\begin{array}{l}\text { Fruit consumed } \\
\text { Cooking fuel } \\
\text { Tea stall }\end{array}$ \\
\hline Azadirachta indica & Neem tree & 8.3 & $\begin{array}{c}\text { Medicinal } \\
\text { Sacred }\end{array}$ & $\begin{array}{l}\text { Children playing } \\
\text { Tea stall }\end{array}$ \\
\hline Ficus religiosa & Sacred fig & 7.6 & $\begin{array}{c}\text { Sacred } \\
\text { Medicinal }\end{array}$ & $\begin{array}{l}\text { Children playing } \\
\text { Eating (lunch) } \\
\text { Flower vendor } \\
\text { Socializing } \\
\text { Washing clothes } \\
\text { Washing dishes } \\
\end{array}$ \\
\hline Albizia saman & Rain tree & 6.5 & $\begin{array}{l}\text { Ornamental } \\
\text { Shade }\end{array}$ & $\begin{array}{l}\text { Breaking stones } \\
\text { Making incense sticks } \\
\text { Playing cricket } \\
\text { Socializing } \\
\text { Washing clothes }\end{array}$ \\
\hline
\end{tabular}


Table 1. Cont.

\begin{tabular}{ccccl}
\hline Scientific Name & Common Name & $\begin{array}{c}\text { Relative } \\
\text { Abundance }\end{array}$ & Uses & $\begin{array}{l}\text { Activities Observed } \\
\text { (Non-Exhaustive) }\end{array}$ \\
\hline Muntingia calabura & Singapore cherry & 6.5 & Fruit & $\begin{array}{l}\text { Fruit consumed } \\
\text { Washing dishes }\end{array}$ \\
\hline Pongamia pinnata & Pongam tree & 5.6 & $\begin{array}{l}\text { Fruit and leaves } \\
\text { consumed } \\
\text { Shade } \\
\text { Grooming } \\
\text { Making incense sticks } \\
\text { Socializing } \\
\text { Washing clothes }\end{array}$ \\
\hline Mangifera indica & Indian mango tree & 4.0 & Fruit & $\begin{array}{l}\text { Children playing } \\
\text { Playing carrom } \\
\text { Socializing }\end{array}$ \\
\hline Swietenia macrophylla & $\begin{array}{l}\text { Big-leaved } \\
\text { mahogany }\end{array}$ & 3.3 & Shade & Playing carrom \\
\hline Psidium guajava & Guava tree & 3.1 & Fruit & Making Brooms \\
\hline
\end{tabular}

The most common plants were Ocimum sanctum (holy basil) and Aloe vera (Indian aloe), both with important medicinal properties (the holy basil is also a very important sacred plant in the Indian context). Plants with ornamental and medicinal uses were almost equal in proportion (Figure 2). Epipremnum aureum (money plant), Rosa species (rose) and Jasminum species (jasmine) were the most common ornamental plants, present in more than $60 \%$ of slums. A small proportion of plants were grown for their fruits such as Carica papaya (papaya), Musa paradisiaca (banana), Momordica charantia (bitter gourd), Dolichos lablab (hyacinth bean) and Solanum lycopersicum (tomato). Plants grown for consumption included Ricinus communis (castor), Oxalis corniculata (common sorrel), and Piper betle (betel plant). Notably, almost all the plants encountered were actively planted by the slum residents.

Figure 2. Proportional distribution of attributes of shrubs, herbs and creepers in slums of Bangalore. The second pie is a further breakdown of the plants used for medicinal purposes with multiple uses.

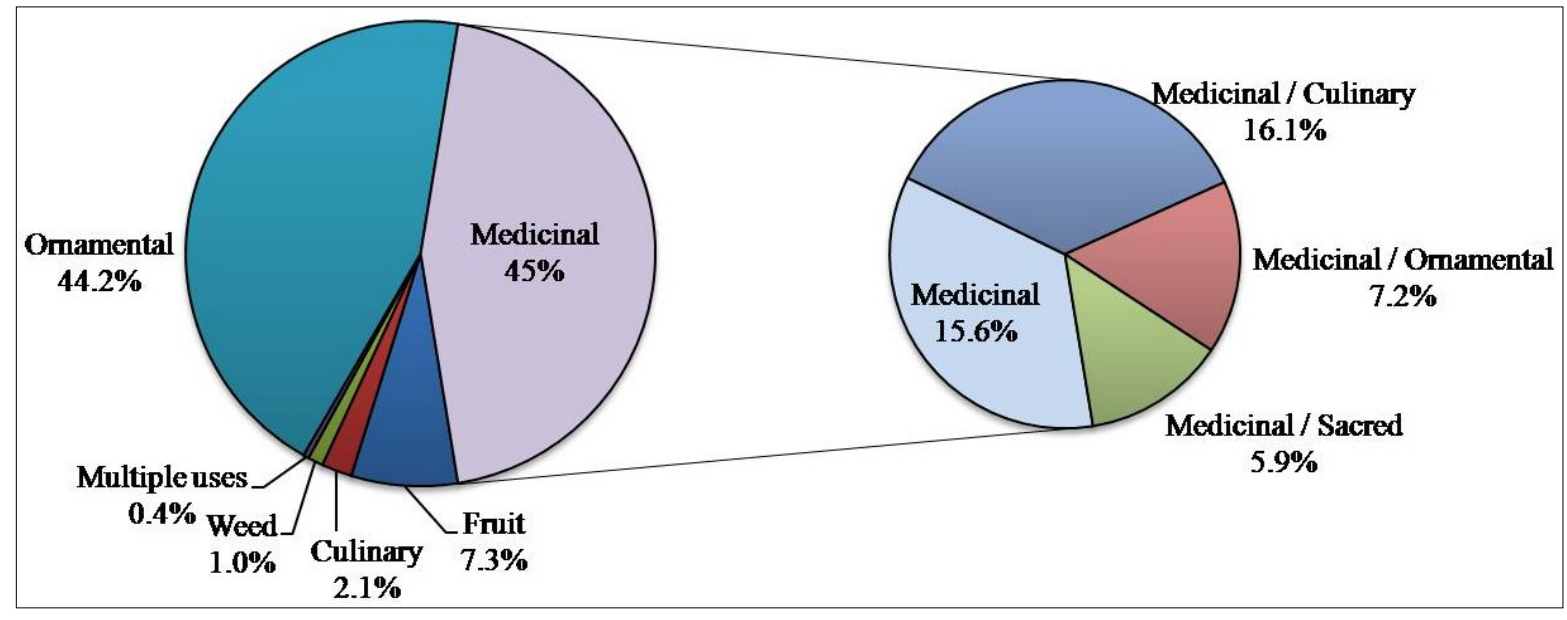




\subsection{Sacred Species}

There were six species of flora in slums that were sacred (in the Hinduism tradition): four species of trees, and two species of herbs. Sacred trees accounted for about $10 \%$ of the total tree population across slums with 63 individuals as enumerated in Table 2. As many as $61 \%$ of slums had at least one sacred tree. Sacred trees were most frequently encountered next to temples, and had the largest canopy cover amongst all trees in slums. In addition to the trees known to be sacred in the Hindu religion, we encountered seven individuals from five species of trees: rain tree, pongam tree, Delonix regia (gulmohar), Gmelina arborea (gumhar) and Markhamia lutea (Nile tulip), with symbols of sacred worship such as the presence of garlands, sacred threads, or anointing with vermilion and turmeric. These species are not commonly believed to be sacred, but were being worshipped due to the personal faith/belief of the slum dwellers.

Table 2. Sacred trees in slums of Bangalore.

\begin{tabular}{llc}
\hline \multicolumn{1}{c}{ Scientific Name } & Common Name & No. of Individuals \\
\hline Ficus religiosa & Sacred fig & 32 \\
Azadirachta indica & Neem tree & 18 \\
Ficus racemosa & Cluster fig & 2 \\
Ficus religiosa + Azadirachta indica & Sacred fig + neem & 2 \\
Pithecellobium dulce & Manila tamarind & 2 \\
Albizia saman & Rain tree & 2 \\
Pongamia pinnata & Pongam tree & 2 \\
Delonix regia & Gulmohar & 1 \\
Gmelina arborea & Gumhar & 1 \\
Markhamia lutea & Nile tulip & 1 \\
\hline
\end{tabular}

The sacred herbs encountered were holy basil and Ruta graveolens (common rue). Of the 44 slums surveyed, holy basil (locally known as tulsi) was present in 41 slums, while common rue was present in four. As mentioned previously, holy basil was the most commonly found species of plants across the slums. The wide presence of the plant and the fact that it is cultivated by slum residents (and not growing spontaneously) indicates the crucial role it plays in the Indian culture.

\subsection{Utility of Tree Species}

Trees appeared to have an important utility function as physical entities, beyond their species-specific sacred, cultural or other properties. Most trees were observed to support clotheslines. Other practical uses include supporting tents, wires, and more (Table 3). About $10 \%$ of the trees supported multiple uses (supporting a combination of clotheslines, tents and/or wires, and bearing holy symbols). Tree shade is a sought-after quality in slums, providing respite from the hot tropical sun. A range of occupations were observed taking place under tree canopies, including the sale of flowers, making of brooms and incense sticks, and the operation of mechanic shops, tea stalls and telephone booths. Women in slums were observed conducting domestic chores such as cooking (using fuel wood), washing clothes and dishes, and grooming (such as oiling each other's hair, combing and removal of lice) under tree canopies; while children were often found to be playing under the shade of 
trees. The most commonly observed activity, however, was of groups of people sitting under tree canopies and conversing/socializing. These activities were tabulated against the tree species under which they were observed, some mentioned in Table 1. Ficus religiosa (sacred fig) was the tree species with the most number of activities observed, followed by pongam tree and rain tree.

Table 3. Overall utility of trees in slums of Bangalore.

\begin{tabular}{lc}
\hline \multicolumn{1}{c}{ Utility } & Percentage of total tree population \\
\hline Clothesline & 35.3 \\
Holy symbols & 6.9 \\
Wire support & 4.9 \\
Tent support & 4.5 \\
Photograph stand & 0.5 \\
Switch board support & 0.5 \\
Hoardings & 0.2 \\
Lamp post & 0.2 \\
Puncture shop & 0.2 \\
Storage area & 0.2 \\
\hline
\end{tabular}

\subsection{Green Preferences}

The slum dwellers responded positively to the survey regarding their preferences for a green neighbourhood. Most respondents were women who were keen on improving their neighbourhood. About half of the respondents wanted more trees in their surroundings, and largely preferred the pongam tree. Others did not desire more trees, citing land issues such as lack of space and ownership (Table 4). However, all the respondents preferred potted plant species and desired more of these in their neighbourhood.

Table 4. Tree preferences in slums of Bangalore-response of slums dwellers to an open-ended survey.

\begin{tabular}{lcl}
\hline \multicolumn{1}{c}{ Tree of Choice } & No. of Slums & \multicolumn{1}{c}{ Reason } \\
\hline None & 23 & No space/Ownership issues/Plenty of trees \\
Pongamia pinnata & 14 & Shade \\
Azadirachta indica & 7 & Shade/Health \\
Mangifera indica & 3 & Fruits \\
Michelia champaca & 2 & Fragrance/Flowers \\
Cocos nucifera & 1 & Compact tree with small basal area \\
Flowering trees & 1 & Flowers \\
Muntingia calabura & 1 & Fruits \\
Shade-giving & 1 & Shade \\
Syzigium cumini & 1 & Fruits \\
\hline
\end{tabular}

\subsection{Innovative Gardening}

With space constraints being a characteristic feature of slums, there were more potted plants than those growing directly from the ground. The pots used were highly innovative addressing key issues 
such as limitation of space and finances. The types of pots seen were earthen pots, plastic pots, cemented structures, plastic bags, discarded paint containers, earthen water pots, plastic buckets, metallic cans, hindalium pots (an alloy of aluminium), battery cans and aluminium buckets. The potted plants were located on windowsills, parapets, roofs, etc. (Figure 3a-c). Although some slums had no trees, all of them had plants with a species richness range of 1-39.

Figure 3. Types of pots for plants in slums of Bangalore-(a) Plastic buckets, plastic tub and discarded paint can. (b) Hindalium (aluminium) container, earthen and plastic pots. (c) Holy basil in an earthen pot with sacred markings.

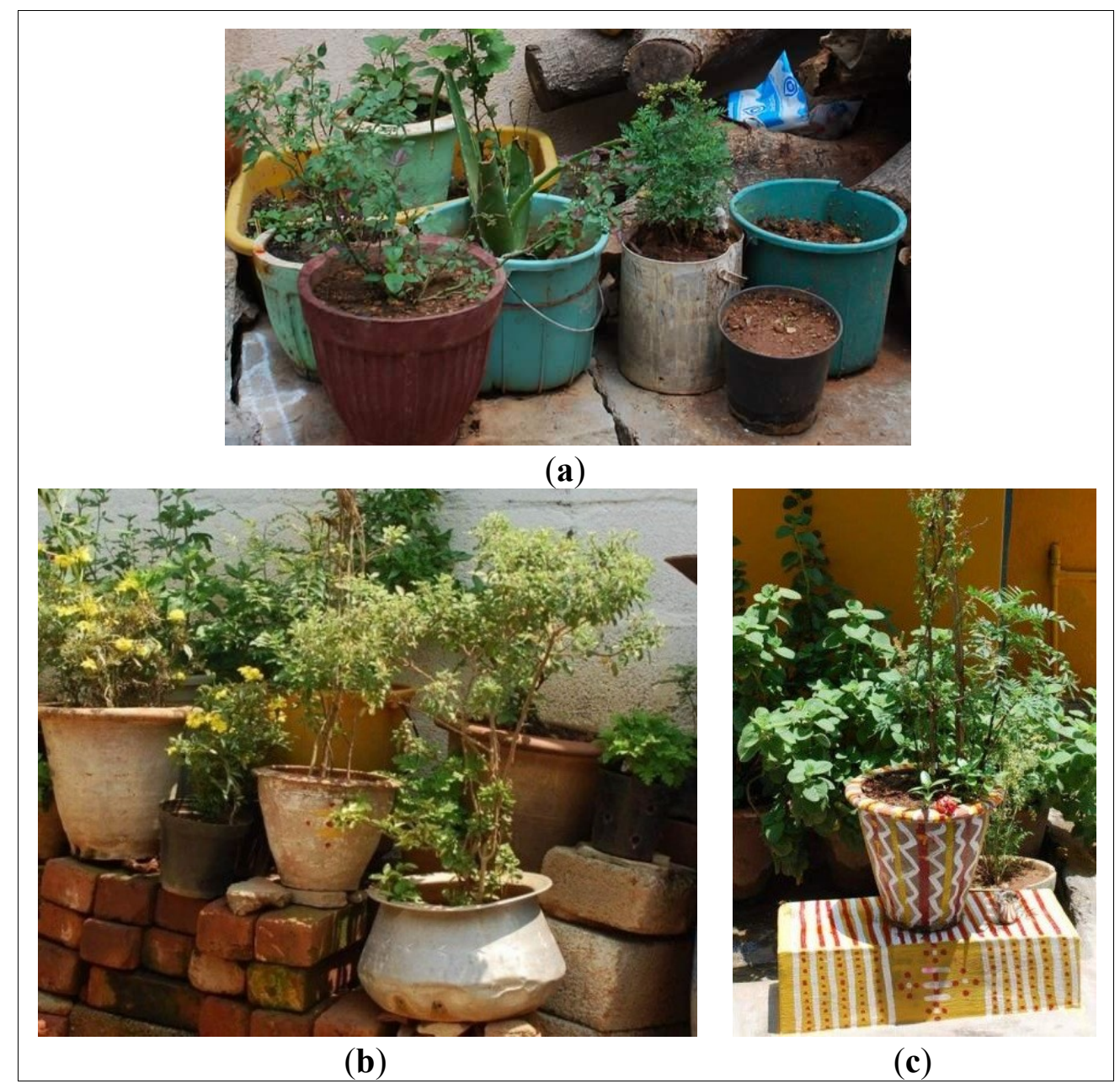

\section{Discussion}

Our results suggest that species distribution and composition are strongly interrelated with social, cultural and economic activities in slums. Urban greenery is evidently a resource that benefits the urban poor as well and is not limited to the upper strata of the society [7,30]. Our results also seem to refute the theory that lower socio-economic groups tend to overwhelmingly prefer utilitarian species $[31,32]$. Although we find a strong preference for utilitarian plants, close to half the plant species are ornamental in nature. 


\subsection{Health and Well-Being}

Urban greenery is often positively correlated with better health and mental well-being for city residents $[6,7,11,33]$. Nearly half the tree population we encountered in slums has medicinal properties, while every one out of three trees we encountered is fruit bearing. The drumstick tree provides an excellent example of this, being the most frequently encountered species, with medicinal as well as culinary uses. Also known as a "miracle tree", drumstick fruits and leaves provide rich sources of proteins, vitamins and minerals, and are known to play a vital role in meeting nutritional deficiencies and alleviating poverty [26,27,34]. Some slum residents and nature enthusiasts in Bangalore indicate in discussions that drumstick trees were intentionally planted in slums during the 1980s to reduce malnutrition. However, we could not trace any official records that verify this claim. The coconut tree, accounting for $13 \%$ of the sampled population, is widely known as "Kalpavriksh", meaning the tree which provides everything. It is nutritious, medicinal and provides many products used for various daily needs including coconuts for consumption, coconut husk for fuel, and fibre for constructing broomsticks [26]. The third most frequently found tree species-neem-is sacred and medicinal. Every part of the tree is used in traditional medicine. Thus, we find that the majority of the trees found in slums have multiple uses, and are of high economic value.

This pattern is observed in shrubs, herbs and creepers as well. Most plant species in slums have medicinal properties and are used for treating various discomforts and ailments of the digestive system [29]. The most commonly encountered plant species such as holy basil, Indian aloe and country borage address stomach disorders [29]. Ailments of this kind frequently plague the urban poor in South Asian cities [24,35,36]. According to the World Health Organization [37], nearly 65\% of the Indian population is dependent on traditional herbal medicine for primary healthcare. Kassam et al. [38] further maintain that the usage of medicinal plants contributes to health security and sovereignty.

Sacred species were important features in most study sites. Ficus religiosa is sacred to both Hinduism and Buddhism, and indispensable in many Hindu rituals. The species has been referred to in many ancient holy texts in India. It has therapeutic properties and is extensively used in traditional medicine to treat a wide range of ailments of the nerves, stomach, intestine, skin and reproductive system $[26,27,39,40]$. The wide prevalence of holy basil can also be attributed to its sacredness. We find that most sacred plants encountered in our study also have important medicinal properties. The presence of trees and plants that heal is important in slums as it provides an inexpensive and readily available source of healthcare for common ailments suffered by the urban poor, and promotes health security and self-reliance at least with regard to minor ailments.

\subsection{Boosting Livelihoods}

We observe that trees in slums are used beyond their innate qualities and act as livelihood components as discussed earlier. Trees act as pillars of support in such settlements - figuratively and literally by bearing tents, clotheslines, wires, etc. The role they play, although basic, is critical in cramped squatter settlements, where community space is at a premium, with over $10 \%$ of the trees used for multiple roles. Trees clearly provide important elements in the daily routine of slum residents and can be considered as an extended part of their dwelling area. Tree canopies provide a platform 
for residents to carry out various economic activities. Considering the fact that a majority of the below-poverty-line (BPL) population of Bangalore live in slums [24], home-based income generating activities could contribute to improving livelihoods.

Apart from low income, coping with food shortage is an integral part of poverty alleviation and improving livelihoods. For instance, slum residents are known to spend over $60 \%-80 \%$ of the monthly household income on basic food in the Lima slums of Peru and the Kibera slums of Nairobi $[12,13,41]$. However, in both countries, urban agriculture has contributed positively towards food security in slums. In the Lima slums, families involved in urban agriculture have been able to add an indirect income of almost $10 \%$ with their garden produce, which is significant in relation to the household economies. However, urban agriculture is difficult to practice in densely populated slums with lack of space. The residents of the congested Kibera slums have adapted to space constraints by actively pursuing a new form of urban agriculture called sack gardening, where vegetables are planted into large sacks filled with soil. Similar to the Kibera slums, there is severe space constraint in Bangalore's slums. This form of agriculture might be of relevance to Bangalore as glimpses of innovative gardening were observed in the city's slums too. Apart from using readily available materials for creating small home gardens, the slum residents showed enthusiasm for increasing potted plants in their neighbourhoods. Moreover, our results suggest that close to $25 \%$ of plants encountered were grown for food or had other culinary uses. Recognizing this affiliation with home gardening, Bangalore's slum inhabitants could be introduced to techniques such as sack gardening that may help enhance self-sustenance, ultimately improving livelihoods.

\subsection{Social Capital}

Social capital encompasses social relationships that nurture mutually beneficial actions within communities, improving productivity [15]. Studies suggest that social capital contributes to economic growth and household food security, consequently reducing poverty [13,15]. Strong social relationships within communities facilitate resource sharing, ultimately benefiting the community and facilitating the access to financial, natural and human capital [42]. In some poor communities in Bangkok, both environmental targets and social development goals were met at the same time due to high social capital [43].

Socializing with neighbours is an important aspect of increasing social capital [15]. Slum dwellers in Bangalore were often seen gathering together under tree canopies and communicating. Social interaction in green spaces can improve bonding and create a better sense of community $[44,45]$. Greenery in low income areas of the city provides a platform for older residents to integrate socially, improving their mental health and longevity [44]. Both greenery and social interactions in such surroundings can significantly reduce aggression [30,46], which can be quite high in the urban slum context in South Asia [47]. Cattell et al. [45] further suggest that social ties can improve tolerance among neighbours and increase vitality of the community as a unit. Our research demonstrates the importance of tree canopies in providing community spaces for socializing in cramped urban slums, thus potentially increasing social cohesion in the context of urban poverty.

Apart from normal social interactions amongst communities, knowledge sharing is a crucial resource that may aid community building [48]. Traditional ecological knowledge can be an important 
tool in resource management and distribution [49]. Social learning is necessary in collaborative management of resources [50]. In the context of Bangalore's slums, this knowledge could range from information on farming/gardening to sharing health wisdom. Usage of traditional medicine within households is informally acquired knowledge, passed on from one generation to another [51]. Similar to the importance of social-ecological memory for better management of urban gardens [52], health remedies in squatter settlements might be rooted in such memory. Although there are several texts that describe ailments and the appropriate remedies for the same, this knowledge is not inclusive as illiteracy is high among the poor [24]. Health wisdom in India is often an oral tradition, with community structure and social interactions being imperative for its existence and transmittance [51]. Tree canopy-created community centres in Bangalore's slums may play a major role in facilitating the survival and transmittance of this wealth of knowledge. However, further research is needed to know precisely the nature of interactions, including what is discussed, with whom and when, in these green community spaces.

\section{Conclusions}

Vegetation in slums of Bangalore appears to play a significant role in improving social capital, livelihoods, health and nutrition. Yet despite the evident socio-cultural dependency of slum dwellers on greenery, vegetation in slums remains low. With severe space and financial constraints, the urban poor still manage to grow potted plants using innovative resources. Sacred fig and pongam tree were noticed to be hotspots of social activities and most slum residents indicated a preference for planting more pongam trees in their surroundings. Pongam has a narrow trunk combined with medium-sized, dense canopy that enables it to be planted in limited space, and yet to provide respite from heat in Bangalore's slums. Policy makers, government agencies, NGOs, and other agencies working towards the alleviation of urban poverty need to acknowledge the significance of greenery and include a green agenda in the strategies they employ. For instance, policy makers could organize workshops on sack gardening and other forms of urban agriculture that might further enhance the livelihoods of the city's poor. A well-thought-out and inclusive strategy of greening should be employed wherein the preferences of slum residents are used to guide interventions and to monitor programme sustainability and success. Vegetation in slums functions as a common pool resource and should be expanded and managed accordingly.

\section{Acknowledgments}

We thank Raja R. for assistance with data collection and Somajita Paul for GIS assistance. We are grateful to Michael Manthey, Universität Greifswald, Germany; for his valuable inputs. This research was possible due to financial support from Rosa Luxemburg Stiftung, Germany and SIDA, Sweden to Divya Gopal; and with funding from a USAID PEER grant to Harini Nagendra.

\section{Author Contributions}

Divya Gopal conceived and designed the study, collected and analyzed the data, and wrote the paper. Harini Nagendra jointly designed the study, assisted in analysis, and co-wrote the paper. 


\section{Supplementary Materials}

Supplementary materials can be accessed at: http:/www.mdpi.com/2071-1050/6/5/2459/s1.

\section{Conflicts of Interest}

The authors declare no conflict of interest.

\section{References}

1. United Nations. World Urbanization Prospect: The 2011 Revision; United Nations: New York, NY, USA, 2012.

2. TEEB Manual for Cities: Ecosystem Services in Urban Management. Available online: http://www.teebweb.org/publication/teeb-manual-for-cities-ecosystem-services-in-urban-management (accessed on 15 December 2013).

3. Bowler, D.; Buyung-Ali, L. Urban greening to cool towns and cities: A systematic review of the empirical evidence. Landsc. Urban Plan. 2010, 97, 147-155.

4. Nowak, D.J.; Crane, D.E.; Stevens, J.C. Air pollution removal by urban trees and shrubs in the United States. Urban For. Urban Green. 2006, 4, 115-123.

5. Wong, N.H.; Tan, A.Y.K.; Tan, P.Y.; Chiang, K.; Wong, N.C. Acoustics evaluation of vertical greenery systems for building walls. Build. Environ. 2010, 45, 411-420.

6. Sugiyama, T.; Leslie, E.; Giles-Corti, B.; Owen, N. Associations of neighbourhood greenness with physical and mental health: Do walking, social coherence and local social interaction explain the relationships? J. Epidemiol. Community Health 2008, 62, e9.

7. Maas, J.; Verheij, R.A.; de Vries, S.; Spreeuwenberg, P.; Schellevis, F.G.; Groenewegen, P.P. Morbidity is related to a green living environment. J. Epidemiol. Community Health 2009, 63, 967-973.

8. Jaganmohan, M.; Vailshery, L.; Gopal, D.; Nagendra, H. Plant diversity and distribution in urban domestic gardens and apartments in Bangalore, India. Urban Ecosyst. 2012, 15, 911-925.

9. Cilliers, S.; Siebert, S.; Davoren, E.; Lubbe, R. Social Aspects of Urban Ecology in Developing Countries, with an Emphasis on Urban Domestic Gardens. In Applied Urban Ecology: A Global Framework; Richter, M., Weiland, U., Eds.; Blackwell Publishing Ltd.: West Sussex, UK, 2012; pp. 123-128.

10. Kuo, F. Coping with poverty impacts of environment and attention in the inner city. Environ. Behav. 2001, 33, 5-34.

11. Van den Berg, A.E.; Maas, J.; Verheij, R.A.; Groenewegen, P.P. Green space as a buffer between stressful life events and health. Soc. Sci. Med. 2010, 70, 1203-1210.

12. Ninez, V. Working at half-potential: Constructive analysis of home garden programmes in the Lima slums with suggestions for an alternative approach. Food Nutr. Bull. 1985, 7, 1-5.

13. Gallaher, C.M.; Kerr, J.M.; Njenga, M.; Karanja, N.K.; WinklerPrins, A.M.G.A. Urban agriculture, social capital, and food security in the Kibera slums of Nairobi, Kenya. Agric. Human Values 2013, 30, 389-404. 
14. Van Leeuwen, E.; Nijkamp, P.; de Noronha Vaz, T. The multifunctional use of urban greenspace. Int. J. Agric. Sustain. 2010, 8, 20-25.

15. Krishna, A. Active Social Capital; Columbia University Press: New York, NY, USA, 2002.

16. Rakodi, C. A livelihoods approach-Conceptual issues and definitions. In Urban Livelihoods: A People-Centred Approach to Reducing Poverty; Rakodi, C., Lloyd-Jones, T., Eds.; Earthscan: Sterling, VA, USA, 2002; pp. 3-22.

17. Martin, K.S.; Rogers, B.L.; Cook, J.T.; Joseph, H.M. Social capital is associated with decreased risk of hunger. Soc. Sci. Med. 2004, 58, 2645-2654.

18. Aggarwal, S.; Butsch, C. Environmental and Ecological Threats in Indian Mega Cities. In Applied Urban Ecology: A Global Framework; Richter, M., Weiland, U., Eds.; Blackwell Publishing Ltd.: West Sussex, UK, 2012; pp. 66-81.

19. Sudhira, H.S.; Ramachandra, T.V.; Subrahmanya, M.H.B. Bangalore. Cities 2007, 24, 379-390.

20. Jawaharlal Nehru National Urban Renewal Mission. Revised City Development Plan: Bangalore; Jawaharlal Nehru National Urban Renewal Mission: New Delhi, India, 2009; Volume 3.

21. Nagendra, H.; Gopal, D. Street trees in Bangalore: Density, diversity, composition and distribution. Urban For. Urban Green. 2010, 9, 129-137.

22. Nagendra, H.; Gopal, D. Tree diversity, distribution, history and change in urban parks: Studies in Bangalore, India. Urban Ecosyst. 2011, 14, 211-223.

23. Sudha, P.; Ravindranath, N. A study of Bangalore urban forest. Landsc. Urban Plan. 2000, 47, 47-63.

24. National Institute of Urban Affairs. Urban Poverty Reduction Strategy for Bangalore; National Institute of Urban Affairs: New Delhi, India, 2008.

25. Nagendra, H.; Nagendran, S.; Paul, S.; Pareeth, S. Graying, greening and fragmentation in the rapidly expanding Indian city of Bangalore. Landsc. Urban Plan. 2012, 105, 400-406.

26. Neginhal, S. Golden Trees, Greenspaces, and Urban Forestry; Self published: Bangalore, India, 2006.

27. Krishen, P. Trees of Delhi; Penguin Books: New Delhi, India, 2006.

28. Kehimkar, I. Common Indian Wild Flowers; Oxford University Press: Mumbai, India, 2000.

29. Kurian, D.J. Plants that Heal; Oriental Watchman Publishing House: Pune, India, 2004.

30. Kuo, F.; Sullivan, W. Aggression and violence in the inner city effects of environment via mental fatigue. Environ. Behav. 2001, 33, 543-571.

31. Martin, C.A.; Warren, P.S.; Kinzig, A.P. Neighborhood socioeconomic status is a useful predictor of perennial landscape vegetation in residential neighborhoods and embedded small parks of Phoenix, AZ. Landsc. Urban Plan. 2004, 69, 355-368.

32. Lubbe, C.S.; Siebert, S.J.; Cilliers, S.S. Political legacy of South Africa affects the plant diversity patterns of urban domestic gardens along a socio-economic gradient. Sci. Res. Essays 2010, 5, 2900-2910.

33. Guite, H.F.; Clark, C.; Ackrill, G. The impact of the physical and urban environment on mental well-being. Public Health 2006, 120, 1117-1126.

34. Pandey, C.B.; Lata, K.; Venkatesh, A.; Medhi, R.P. Diversity and species structure of home gardens in South Andaman. Trop. Ecol. 2006, 47, 251-258.

35. Gupta, H.; Baghel, A. Infant mortality in the Indian slums: Case studies of Calcutta metropolis and Raipur city. Int. J. Popul. Geogr. 1999, 5, 353-366. 
36. Vashishtha, V. Rising urbanization of poverty a blot on the shining armor India urban poverty report 2009. Indian Pediatr. 2009, 46, 875-876.

37. World Health Organization (WHO). Traditional Medicine Strategy 2002-2005; WHO: Geneva, Switzerland, 2002.

38. Kassam, K.-A.; Karamkhudoeva, M.; Ruelle, M.; Baumflek, M. Medicinal Plant Use and Health Sovereignty: Findings from the Tajik and Afghan Pamirs. Hum. Ecol. Interdiscip. J. 2010, 38, 817-829.

39. Sitaramam, V.; Jog, S.; Tetali, P. Ecology of Ficusreligiosa accounts for its association with religion. Curr. Sci. 2009, 97, 637-640.

40. Singh, D.; Singh, B.; Goel, R.K. Traditional uses, phytochemistry and pharmacology of Ficusreligiosa: A review. J. Ethnopharmacol. 2011, 134, 565-583.

41. Pascal, P.; Mwende, E. A Garden in a Sack: Experiences in Kibera, Nairobi. Urban Agric. Mag. 2009, 21, 38-40.

42. Bebbington, A.; Perreault, T. Social Capital, Development, and Access to Resources in Highland Ecuador. Econ. Geogr. 1999, 75, 395-418.

43. Fraser, E. Urban ecology in Bangkok, Thailand: Community participation, urban agriculture and forestry. Environments 2002, 30, 37-50.

44. Kweon, B.-S.; Sullivan, W.C.; Wiley, A.R. Green Common Spaces and the Social Integration of Inner-City Older Adults. Environ. Behav. 1998, 30, 832-858.

45. Cattell, V.; Dines, N.; Gesler, W.; Curtis, S. Mingling, observing, and lingering: Everyday public spaces and their implications for well-being and social relations. Health Place 2008, 14, 544-561.

46. Sampson, R.J.; Raudenbush, S.W.; Earls, F. Neighborhoods and violent crime: A multilevel study of collective efficacy. Science 1997, 277, 918-924.

47. Sambisa, W.; Angeles, G.; Lance, P.M.; Naved, R.T.; Thornton, J. Prevalence and correlates of physical spousal violence against women in slum and nonslum areas of urban Bangladesh. J. Interpers. Violence 2011, 26, 2592-2618.

48. Mchombu, K. Sharing Knowledge for Community Development and Transformation: A Handbook; Oxfam Canada: Ottawa, ON, Canada, 2004.

49. Berkes, F.; Colding, J.; Folke, C. Rediscovery of traditional ecological knowledge as adaptive management. Ecol. Appl. 2000, 10, 1251-1262.

50. Schusler, T.M.; Decker, D.J.; Pfeffer, M.J. Social Learning for Collaborative Natural Resource Management. Soc. Nat. Resour. 2003, 16, 309-326.

51. Verma, A.; Singhal, A.; Singh, D. Local health wisdom of rural women using medicinal plants. Indian J. Tradit. Knowl. 2010, 9, 289-293.

52. Barthel, S.; Folke, C.; Colding, J. Social-ecological memory in urban gardens-Retaining the capacity for management of ecosystem services. Glob. Environ. Chang. 2010, 20, 255-265.

(C) 2014 by the authors; licensee MDPI, Basel, Switzerland. This article is an open access article distributed under the terms and conditions of the Creative Commons Attribution license (http://creativecommons.org/licenses/by/3.0/). 